Open Access

\title{
The national entrepreneurship framework conditions in sub-Saharan Africa: a comparative study of GEM data/National Expert Surveys for South Africa, Angola, Mozambique and Madagascar
}

\author{
Mike Herrington ${ }^{1 *}$ and Alicia Coduras ${ }^{2^{*}}$
}

\begin{tabular}{l}
\hline *Correspondence: mherrington@ \\
gemconsortium.org; acoduras@ \\
gemconsortium.org \\
${ }^{1}$ University of Stellenbosch Business \\
School, P.O.Box 1002, Cape Town, \\
Durbanville 7550, South Africa \\
${ }^{2}$ Global Entrepreneurship Research \\
Association (GERA) and Institute \\
Opinometre, Barcelona, Spain
\end{tabular}

* Correspondence: mherrington@ gemconsortium.org; acoduras@ gemconsortium.org

Business Opinometre, Barcelona, Spain

Open Access

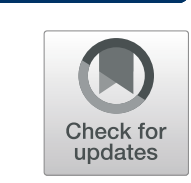

\begin{abstract}
Entrepreneurship is widely argued to be critical for economic development and alleviating extreme poverty. However, entrepreneurship research in sub-Saharan Africa has not received much attention over the last few decades possibly due to a lack of sufficient resources. It is becoming increasingly important as Africa, especially sub-Saharan Africa, is developing rapidly and moving from a resource-based economy to one of innovation and progress. Using data from the Global Entrepreneurship Monitor (GEM), this paper discusses the opinions of national expert informants in Angola, Madagascar, Mozambique and South Africa and looks at the factors which are possibly hindering and inhibiting entrepreneurial development. The results indicate that there are four main inhibitors ranging from lack of access to finance, government policies, regulations and practices for entrepreneurs and the poor levels of entrepreneurship education. Some recommendations are made as to what can be done to assist in promoting economic development.
\end{abstract}

Keywords: National entrepreneurship framework conditions, Sub-Saharan economies, GEM, NES, Main inhibitors of entrepreneurial activity

\section{Introduction}

For decades, the world has looked upon Africa as the "lost continent" where institutions are fragile and weak, economic growth has stalled and where poverty and disease are widespread (Welt De, 2009). However, in recent years Africa's economic pulse has quickened, infusing the continent with new commercial vibrancy. Real GDP rose by $4.9 \%$ from 2001 to 2008 more than twice that of the 1980s and 1990s (OECD, 2012). During this period, the telecommunications, banking and retail sectors flourished, construction boomed and private investment flows surged. At the same time, many countries in sub-Saharan Africa (SSA) such as Nigeria, Angola, Botswana and the Democratic Republic of the Congo became less reliant on raw material mineral extraction and agriculture and started to move towards hightechnology innovation (McKinsey Global Institute Analysis, 2017). 
In its outlook report on the Global Agenda 2015 (World Economic Forum, 2016), WEF identified deepening income inequality and persistent jobless growth as the most important challenges that the world needs to address. Inequality is one of the key challenges in the modern world; it is one of the most visible aspects of a broader and more complex issue and one that entails inequality of opportunity that extends to age, gender, ethnicity and disability. A lack of inclusive growth capable of providing decent jobs and livelihoods for all people within society is seen as the second most critical issue. A shortage of employment opportunities in their countries is seen as a big problem by more than two thirds of the world's population (Asia 62\%, North America 64\%, Europe 71\%, the Middle East and North Africa 70\%, Latin America 79\% and sub-Saharan Africa 88\%) (ILO, 2018).

In spite of better than average growth, Africa still faces many challenges. The current economic situation has brought to light that people, especially the youth, can no longer depend solely on large business and government to create jobs. Across the globe, there is broader awareness and respect for those who start their own businesses to build jobs for themselves and, ideally, employment for others.

Over the past years entrepreneurship research in Africa has not received much attention from academics although this is changing as Africa is emerging as an up and coming economic powerhouse (Atiase, Mahmood, Wang, \& Botchie, 2018; Dvoulety \& Orel, 2019; George, Kotha, Parikh, Alnuaimi, \& Bahaj, 2016; Kuada, 2015; Munemo, 2012; Ratten \& Jones, 2018). Indeed, entrepreneurship and an entrepreneurial mindset are becoming more acknowledged throughout the African continent (George et al., 2016) and studies by Ndulu, Chakraborti, Lijane, Ramachadram, and Wolgin (2007) have shown that entrepreneurship in Africa is one of the factors that has had a positive impact on economic growth. This is especially important in countries within SSA where youth unemployment remains persistently high. Although many young Africans venture into self-employment in the informal sector, Chigunta (2017) agrees that entrepreneurship provides a pathway out of poverty even though many still face complex ecosystem challenges which will be discussed in this paper.

Entrepreneurship is often evoked as a highly relevant conduit and driving force for economic growth when new businesses create more employment through job creation and increased production and the introduction of innovations to the economy. Hence, entrepreneurial activities seem to have a positive relationship with economic growth (Acs, Autio, \& Szerb, 2014; Aghion, 2017; Lafuente, Szerb, \& Acs, 2016; Szerb, Lafuente, Horvath, \& Pager, 2018) and scholars increasingly argue that entrepreneurship is a critical mechanism for alleviating poverty especially in developing and emerging economies (Bruton et al., 2015, Sutton et al., 2019). However, there are strong counter arguments to this as supported by Lafuente, Vaillant, and Leiva (2018) who state that more entrepreneurs are not always good for the economy because incentives that attract hi-tech multinational enterprises are more likely to create greater employment.

Although many African countries are making good economic progress and have high rates of early-stage entrepreneurial activity (Herrington \& Kew, 2017). The results indicate that they nevertheless under-perform compared to other developing countries in Asia and Latin America in terms of GDP per capita. The studies by Lafuente et al. (2016) indicate that economic performance is not necessarily linked to high rates of entrepreneurship but rather to healthy institutional ecosystem settings. Poor institutional development and the 
lack of opportunity-driven entrepreneurship are the most important challenges for African nations (Gomes, Vendrell - Herrero, Mellahi, Angwin, \& Sousa, 2018) suggesting it is time to develop or radically alter current government policies (African Economic Outlook, 2017). In other words, shift policy initiatives from actions directed towards increasing entrepreneurial rates to a more holistic view in which institutional restructuring is necessary to encourage economic development.

As mentioned previously, little is known about entrepreneurship and the entrepreneurial environment in many less-developed societies especially Africa which makes it difficult to understand the underlying factors that influence entrepreneurs in these resource-constrained countries. Although the Global Entrepreneurship Monitor (GEM) reports on many different measures of entrepreneurship in countries around the world and has been doing this since 1999, many African countries are not included (Sheriff, Muffatto, \& Cooper, 2016) due to the high cost of collecting the data. In recent years, a substantial grant from the IDRC (International Development Research Centre) of Canada enabled research to be conducted in ten sub-Saharan African countries (Angola, Botswana, Ethiopia, Ghana, Malawi, Namibia, Nigeria South Africa, Uganda and Zambia) the results of which are reported in this paper.

Africa is a large continent with 55 highly different and heterogeneous countries ranging from those in North Africa which are part of the MENA group of countries to those in Central Africa and in sub-Saharan Africa which include some of the poorest and most densely populated economies. The latter has a diverse history of colonial occupation where tribal heritages are still pronounced (Beugre, 2016). Over the years, there have been immersed political instability exasperated with violent conflict and corruption, low standards of living, health problems, high income inequalities and poor institutional development (Gomes et al., 2018).

The private business sector in most SSA countries is characterized by a few large businesses, and in some countries, especially South Africa anecdotally, the State controls key businesses where competition is not encouraged. Small ventures dominate the rest of the economy and tend not to follow an innovation or value creation strategy (sub-Saharan Africa, 2018). The informal sector contributes between 25 and $65 \%$ of the GDP and 60 and $90 \%$ of employment where it should be noted that these informal businesses are different from formally registered ones in terms of growth and employment creation (Williams, MartinezPerez, \& Kedir, 2017). Informal businesses are frequently associated with necessity-driven entrepreneurship which although not bad do not significantly contribute to economic growth (Herrington \& Kew, 2015, Herrington, Kew, \& Mwanga, 2016 and Herrington \& Kew, 2017). Recent studies have shown that improvements in the entrepreneurial framework are most likely to affect economic growth rather than small, unproductive businesses that tend to employ few people (Sheriff et al., 2016). This paper will focus on the national entrepreneurship framework conditions in South Africa and compare it to other selected SSA countries so as to enhance business development. An absence of a healthy and supportive entrepreneurship framework will not allow economic growth for countries where a significant proportion of the economy relies on the performance of the informal sector.

\section{The Global Entrepreneurship Monitor: a conceptual approach}

GEM or the Global Entrepreneurship Monitor was first conceptualized in 1997 with its first reports published in 1999 involving ten countries, eight from the OECD, the USA 
and Japan (Reynolds, Hay, \& Camp, 1999). Since then, it has expanded to include over 100 economies covering all geographic regions and representing all levels of economic development (Bosma \& Kelley, 2019). GEM represents a primary source of data generated through two research instruments, the Adult Population Survey (APS) and the National Expert Survey (NES). GEM provides a comprehensive set of indicators on entrepreneurship and is now considered to be the most authoritative and informative study on entrepreneurship in the world today.

GEM does primary research on individuals and their entrepreneurial aspirations, intentions and business profiles. It also measures multiple phases of business development from intentions through to mature, established businesses and their discontinuance (www.gemconsortium.org). Key to GEM is the participation of national teams who fund their own research and provide key insights and knowledge about entrepreneurship in their own countries. Each team is usually led by an academic institution responsible for collecting the data and publishing a national report with conclusions and recommendations applicable to their country. The project is overseen by the Global Entrepreneurship Research Association (GERA) who ensures that the survey approach captures as representative as possible a sample of the demographics of the population taking into account shifts in communication habits and rapidly changing technology.

GEMs conceptual framework depicts the multifaceted features of entrepreneurship recognizing the proactive, innovative and risk-responsive behaviour of individuals always in interaction with the environment. The GEM conceptual framework derives from the basic assumption that national economic growth is the result of personal capabilities of individuals to identify and seize opportunities and that this process is affected by environmental factors that influence individuals' decisions to pursue entrepreneurial initiatives. The figure below (Fig. 1) shows the main components and relationships into which GEM divides the entrepreneurial process and how it classifies entrepreneurs according to the level of organizational development (GEM Global Report, 2017/18).

The social, cultural, political and economic context is represented through the National Entrepreneurial Framework Conditions (EFCs) which take into account the advancement of each society through the three phases of economic development (factor-driven, efficiency-driven and innovation-driven).

EFCs, which relate more specifically to the quality of the entrepreneurial ecosystem at a national level, include the following: entrepreneurial finance, government policy, taxes and bureaucracy, government entrepreneurship programmes, entrepreneurship education, research and development transfer, commercial and legal infrastructure, internal market dynamics and entry regulations, physical infrastructure and cultural and social norms. At least four experts from each EFC must be interviewed using a structured standardized questionnaire composed of blocks which are theoretical constructs on each condition as latent variables, making a minimum of 36 experts per country. In order to select a balanced and representative sample, the experts are drawn from the communities of entrepreneurs, government, academics and practitioners in each country. A minimum of $25 \%$ must be entrepreneurs or business people and $50 \%$ must be professionals. Additional aspects such as geographical distribution, gender, involvement in the public versus private sector and level of experience should also be taken into account when balancing the sample. 


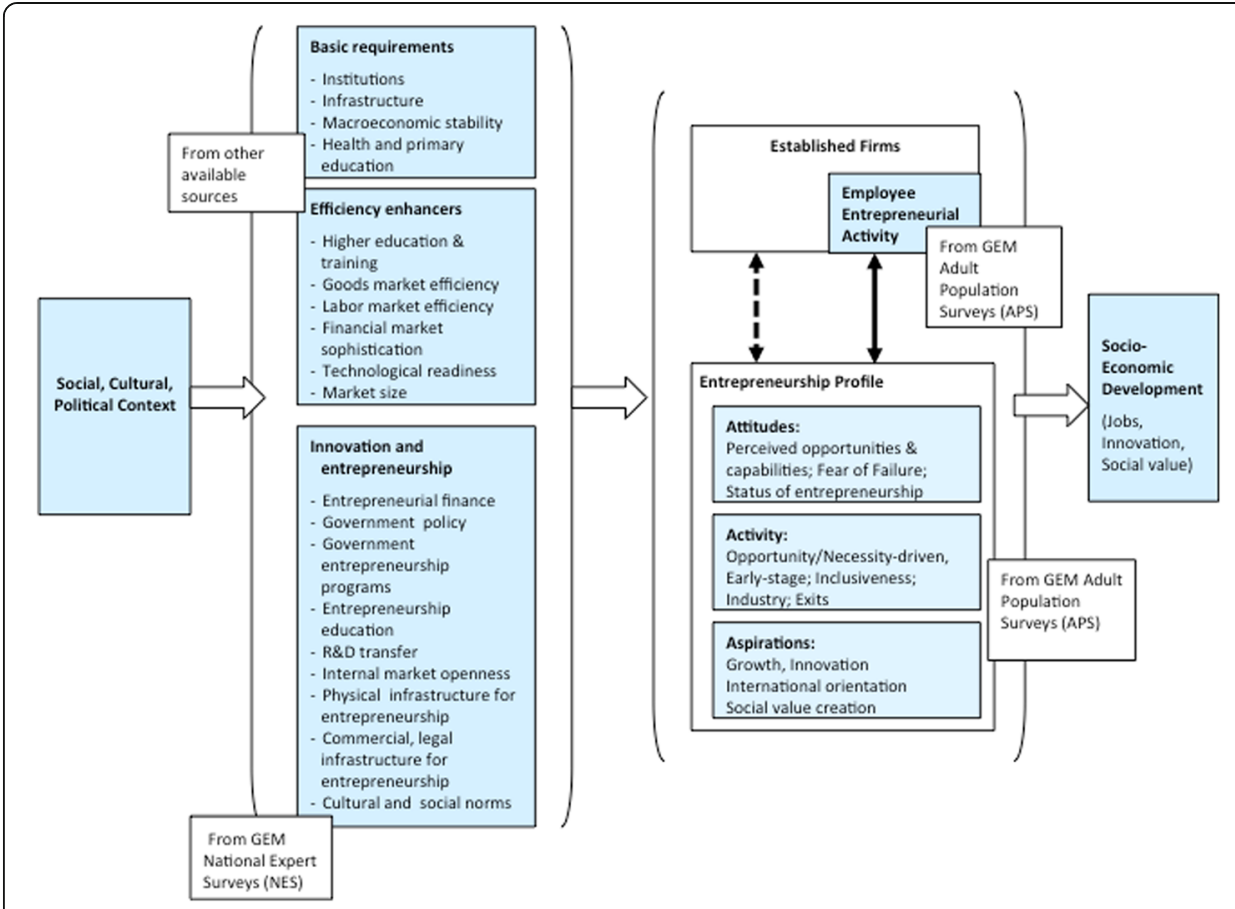

Fig. 1 The GEM conceptual framework. Source: Global Entrepreneurship Monitor Report, 2017/18

\section{Methodology and data}

This study is mainly descriptive hence the statistical methods applied include descriptive tables and graphs plus a set of principal component analyses that provide additional information and details to obtain more accurate interpretations on some specific results.

The data used in this study have been collected via the NES and harmonized by GEM for African countries across the years 2012-2018 thanks to the implementation of the National Experts Survey (NES). The items are statements that are scored by experts using a Likert scale of 9 points where $1=$ completely false and $9=$ completely true. It should be noted that some question blocks are made up of two components or latent variables instead of just one. For example, the education and training condition is usually made up of two components: one that represents entrepreneurship education and training at school level and another that represents this type of education at a post-school level.

\section{Results}

General description of the average state of entrepreneurship framework conditions for GEM Sub-Saharan countries based in the most recent information available

Conducting surveys in Africa is a big challenge both from an economic and logistical point of view. It is a costly process and getting to interview respondents is not always easy because of large distances and in some cases lack of accessibility. Participation in GEM has not been consistent and in some countries, as shown in the table below (Table 1), data has only been collected for 1 year. The most 
consistent countries are South Africa, Egypt and Uganda and many of the subSaharan African countries only participated when the project was supported by the IDRC of Canada.

Analysis of the 12 EFCs for the different African countries is given below in Table 2. The figures are the average scores of a Likert scale of nine points where $1=$ very insufficient and $9=$ very sufficient and which represent the average state of the National Entrepreneurial Conditions at the time of measurement. Depending on the countries, the results cover the last 7 years, from 2012 to 2018. Looking at GEM reports of the last years, it is possible to confirm that the changes that occur in these indicators are slow and progressive, not registering large oscillations unless there is a specific reason that justifies it, such as an economic or social crisis, a structural change, a natural catastrophe or any event of great positive or negative impact in a country. Based upon this, it is possible to take these results as an acceptable estimation of the current situation of the entrepreneurship context in most of these countries. Taking in consideration that a score of five points represents an acceptable state for a condition (although not good), the majority of countries show few conditions that reached an acceptable or good state (highlighted in grey in the table). Indeed, Angola and Mozambique do not show any condition qualifying as acceptable. It should be noted that their NESs was conducted last year in 2018.

Table 1 African countries' participation in the GEM National Expert Survey

\begin{tabular}{|c|c|}
\hline Algeria & 3 years from 2011 to 2013 \\
\hline Angola & 5 years, 2010, 2012, 2013, 2014 and 2018 \\
\hline Botswana & 4 years from 2012 to 2015 \\
\hline Burkina Faso & 3 years from 2014 to 2016 \\
\hline Cameroon & 3 years from 2014 to 2016 \\
\hline Egypt & 7 years, 2008, 2010, 2012, 2015, 2016, 2017 and 2018 \\
\hline Ethiopia & 1 year, 2012 \\
\hline Ghana & 3 years, 2010, 2012 and 2013 \\
\hline Libya & 1 year, 2013 \\
\hline Namibia & 2 years, 2012 and 2013 \\
\hline Nigeria & 2 years, 2011 and 2012 \\
\hline Madagascar & 2 years, 2017 and 2018 \\
\hline Malawi & 2 years, 2012 and 2013 \\
\hline Morocco & 4 years, from 2015 to 2018 \\
\hline Mozambique & 1 year, 2018 \\
\hline Senegal & 2 years, 2015 and 2016 \\
\hline South Africa & 15 years, from 2001 to 2017 except the years 2005 and 2007 \\
\hline Sudan & 1 year, 2018 \\
\hline Tunisia & 4 years, 2009, 2010, 2012 and 2015 \\
\hline Uganda & 7 years, 2014, 2013, 2012, 2010, 2009, 2004 and 2003 \\
\hline Zambia & 3 years, 2010, 2012 and 2013 \\
\hline
\end{tabular}

Source: GEM, seven years 
Table 2 The most recent average state of the 12 EFCs for African countries

\begin{tabular}{|c|c|c|c|c|c|c|c|c|c|c|c|c|c|}
\hline & Year & A & B1 & B2 & $C$ & D1 & D2 & $E$ & $\mathrm{~F}$ & G1 & G2 & $\mathrm{H}$ & 1 \\
\hline Algeria & 2013 & 6.16 & 5.74 & 4.61 & 4.95 & 4.41 & 5.69 & 5.18 & 5.15 & 7.20 & 5.35 & 6.25 & 5.74 \\
\hline ngola* & 18 & 2.59 & 3.65 & 3.65 & 3.13 & 3.22 & 3.85 & 2.72 & 4.55 & 4.98 & 3.57 & .97 & 4.68 \\
\hline Botswana & 2015 & 4.37 & 4.43 & 4.41 & 4.41 & 4.54 & 5.40 & 4.21 & 4.50 & 5.38 & 3.74 & 5.35 & 5.04 \\
\hline urkina Faso & 2016 & 3.24 & 5.49 & 5.78 & 5.13 & 2.63 & 5.27 & 2.99 & 4.68 & 4.90 & 3.80 & 5.31 & 5.40 \\
\hline Cameroon & 2016 & 4.37 & 4.95 & 4.39 & 5.00 & 3.56 & 5.78 & 4.19 & 5.49 & 5.11 & 4.55 & 5.74 & 5.54 \\
\hline gypt & 2018 & 4.39 & 4.26 & 3.50 & 3.98 & 2.33 & 3.72 & 3.46 & 4.48 & 5.13 & 4.38 & 6.52 & 4.56 \\
\hline Ethiopia & 2012 & 4.32 & 6.37 & 5.53 & 4.72 & 4.28 & 5.42 & 4.00 & 4.81 & 7.04 & 4.86 & 5.99 & 5.33 \\
\hline Ghana & 2013 & 4.66 & 4.88 & 3.96 & 4.12 & 3.74 & 5.24 & 3.73 & 5.40 & 5.54 & 5.38 & 5.38 & 5.56 \\
\hline Libya & 2 & 3.85 & 3.62 & 4.73 & 3.15 & 2.54 & 4.14 & 3.29 & 5.24 & 5.76 & 5.11 & 5.36 & 4.52 \\
\hline Namibia & 2013 & 4.68 & 5.31 & 3.82 & 4.30 & 4.99 & 5.58 & 3.62 & 4.99 & 5.44 & 4.63 & 6.28 & 5.76 \\
\hline geria & 12 & 3.96 & 3.55 & 3.58 & 3.60 & 3.76 & 4.39 & 3.37 & 5.17 & 6.61 & 4.28 & 5.49 & 5.78 \\
\hline Madagascar* & 2018 & 2.79 & 3.30 & 3.21 & 3.03 & 2.33 & 5.51 & 3.27 & 4.35 & 5.15 & 3.35 & 4.26 & 3.77 \\
\hline alav & 2 & 3.47 & 4 & 3 & 3 & 3.92 & 5.20 & 2 & b & 9 & 9 & 6 & 4.37 \\
\hline Morocco & 2018 & 3.60 & 3.42 & 3.97 & 3.39 & 1.87 & 4.02 & 2.59 & 4.96 & 4.50 & 3.08 & 6.61 & 3.79 \\
\hline Mozambique* & 2018 & 1.71 & 1.83 & 2.48 & 2.25 & 1.77 & 2.26 & 1.91 & 3.61 & 4.82 & 3.11 & 4.99 & 3.14 \\
\hline Senegal & 2016 & 3.55 & 4.99 & 6.03 & 5.31 & 2.05 & 3.78 & 2.68 & 6.61 & 3.29 & 4.45 & 8.26 & 3.42 \\
\hline South Africa* & 2017 & 4.52 & 4.41 & 3.73 & 3.64 & 3.20 & 4.55 & 3.13 & 4.86 & 5.56 & 3.44 & 5.72 & 4.88 \\
\hline udan & 2018 & 3.89 & 2.49 & 2.69 & 2.66 & 2.47 & 5.32 & 2.94 & 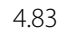 & 7.46 & 5.1 & 4.92 & 4.34 \\
\hline Tunisia & 2015 & 4.64 & 4.28 & 3.01 & 3.92 & 2.07 & 3.62 & 3.04 & 6.28 & 7.51 & 3.10 & 7.25 & 4.36 \\
\hline ganda & 2014 & 4.18 & 4.93 & 3.96 & 4.57 & 4.36 & 5.6 & 3. & 5.56 & 6.35 & 5.11 & 6.01 & 6.10 \\
\hline Zambia & 2013 & 3.44 & 3.82 & 4.21 & 3.87 & 3.69 & 4.43 & 3.02 & 4.61 & 5.54 & 4.90 & 5.22 & 4.75 \\
\hline
\end{tabular}

\section{Strengths and weaknesses of the entrepreneurship context at sub-Saharan countries with recent data}

The results presented in this section cover only South Africa, Angola, Mozambique and Madagascar as they represent the more recent Sub-Saharan participants and will describe the average state of the EFCs within each country comparing it with that achieved by the economic group of GEM countries to where they belong as per the Global Competitiveness Report classification.

Figures 2, 3, 4 and 5 show the main strengths and weaknesses of the entrepreneurship context for these countries as compared to the average state of the entrepreneurial conditions in their respective economic group.

Figure 2 shows that South Africa shows comparable scoring for the EFCs as other efficiency-driven countries (to which south Africa belongs) for the conditions of financing for entrepreneurs, government policies and support, bureaucracy and taxes, school entrepreneurial education and commercial and professional infrastructure and lower in several conditions-physical infrastructure and services access, internal market burdens, government programmes post-school entrepreneurial education and $R \& D$ transfer. The other conditions not mentioned are weaknesses of different degrees. In conclusion, the situation regarding the national entrepreneurial framework for South Africa is 


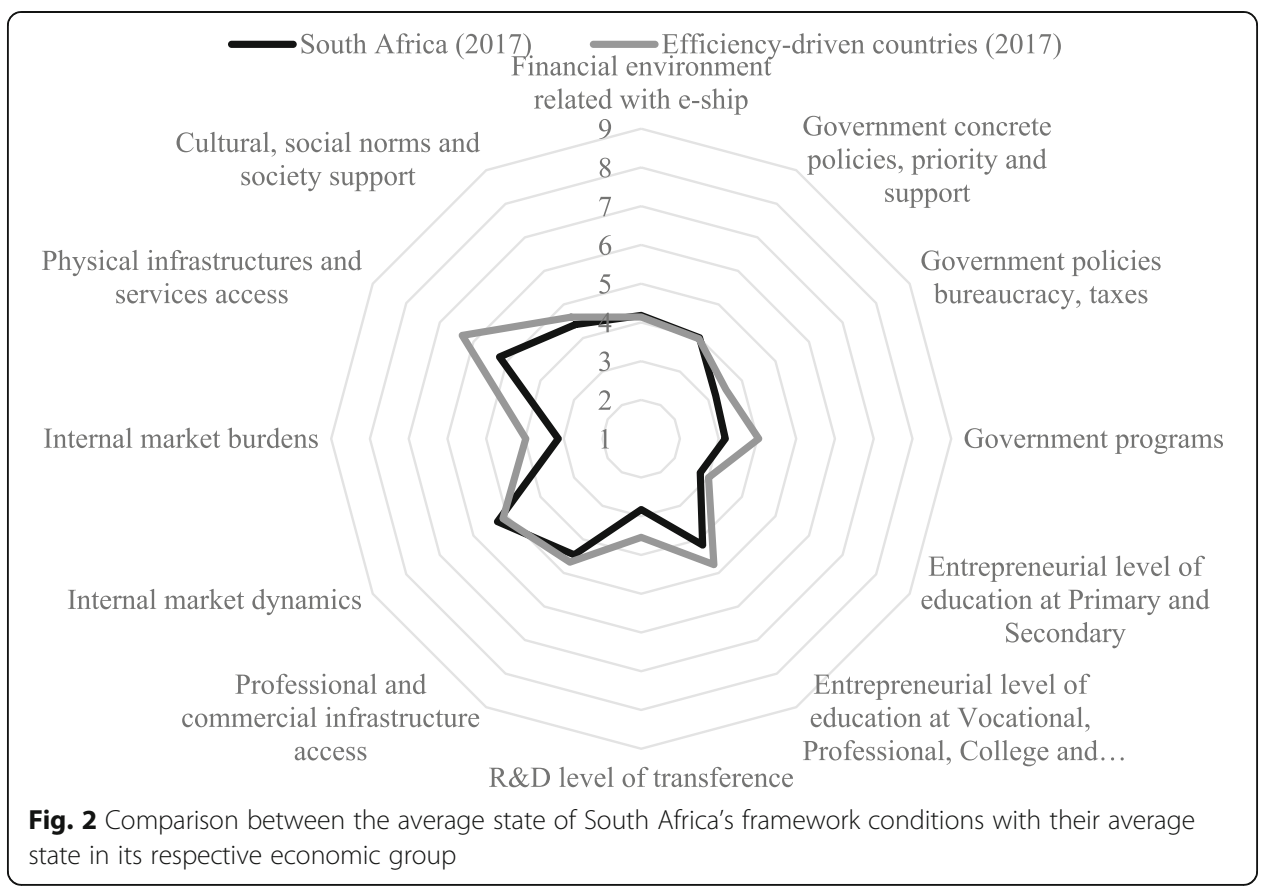

not adequate to support the development of a strong economic contribution from entrepreneurial activity.

Figure 3 shows that the average state of the entrepreneurial ecosystem for Angola is worse than the average of other low-income countries around the world with the exception of internal market dynamics, commercial infrastructure and cultural and social norms. The situation in Angola is not ideal and certain aspects need attention in order to improve the situation

\begin{tabular}{|l} 
Cultural, social norms and \\
society support
\end{tabular}




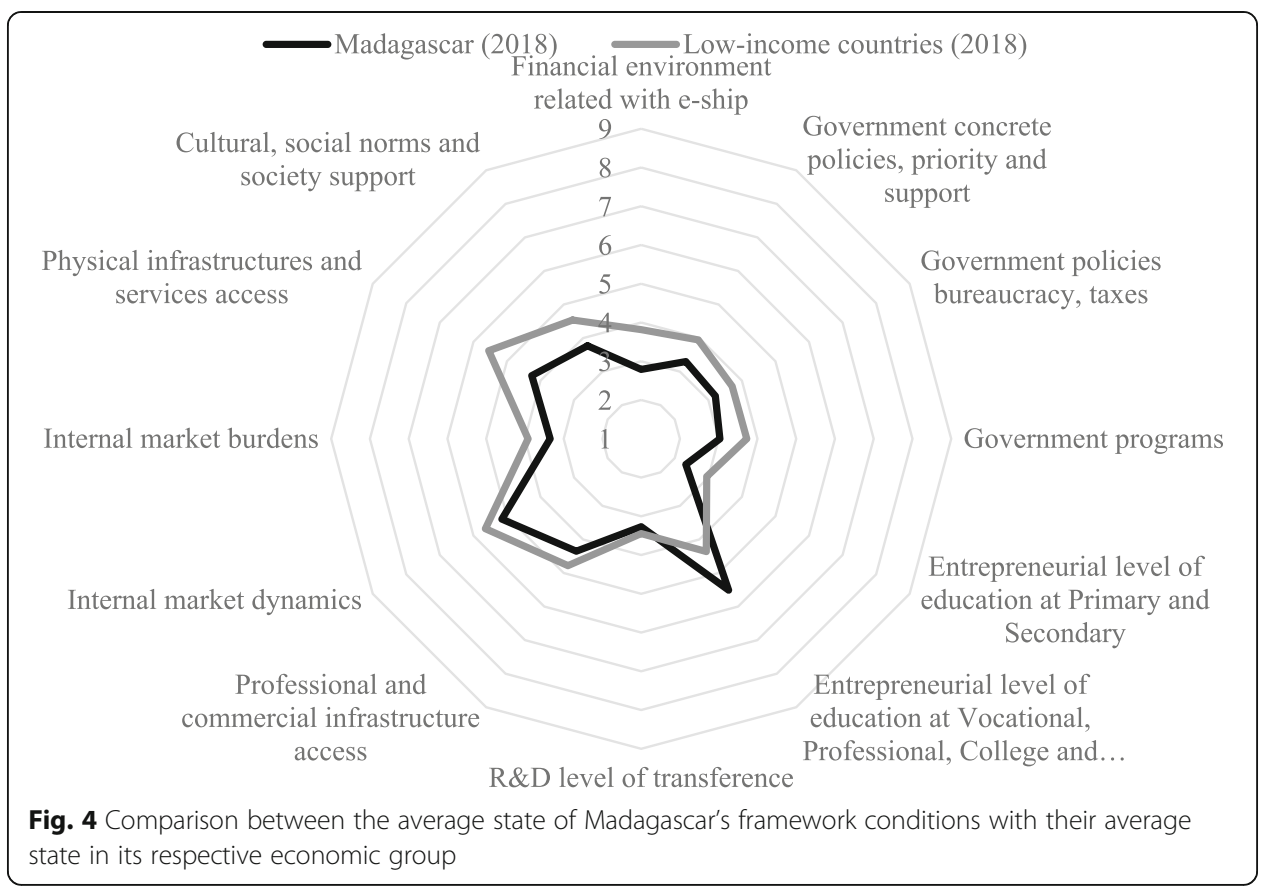

In the case of Madagascar (Fig. 4), the profile shows that all the EFCs with the exception of physical infrastructure and internal market dynamics are far less than the average for low-income countries. In conclusion, the situation in Madagascar is worse than the situation in either Angola or Mozambique and needs serious interventions if the entrepreneurial activity and economic development are to improve.

The situation in Mozambique is even more serious (Fig. 5) than in Madagascar and needs serious invention.

\begin{tabular}{|c|c|c|c|c|c|c|c|} 
Cultural, social norms and \\
society support
\end{tabular}


As a result of this preliminary analysis, it is concluded that the context for the development of entrepreneurial activity is generally weak in the selected countries. Given that analysing in depth the 12 environmental conditions exceeds the purposes of this article, in the next sections, we focus on four that have special relevance in the framework of these countries. The selected conditions are financing for entrepreneurs, government policies and programmes and entrepreneurship education. There are several studies whose conclusions justify choosing these four basic conditions. Thus, for example, when determining the correlates of poverty for inclusive growth in Africa using data of 43 countries, Anyanwu (2013), found out that primary education alone and income inequality are main burdens to reduce poverty while secondary education and higher real per capita GDP show positive correlations with poverty reduction. In the same study, he found out that trade openness has positive but insignificant effect on poverty despite the huge liberalization efforts of African countries. These results suggest that education and government policies and programmes are, at this moment, priority compared to other conditions such as internal market burdens, commercial infrastructure and others because if people are not properly educated and the government does not develop inclusive growth policies, it is going to be hard to develop the complementary conditions that make strong a national entrepreneurship framework.

Additionally, Anyanwu (2013) remarks on his study that "the benefits of the recent economic growth in African countries have not been inclusive and equitably shared. Thus, such growth has not been inclusive because it has not broadened access to sustainable socioeconomic opportunities for more people, countries and regions, while not protecting the vulnerable". As entrepreneurs base their initiatives on the existence of opportunities, the lack of access to many of them for a big proportion of the population, and especially of youth, strongly conditions that many potential entrepreneurs try to put their ideas on practice. Financing for entrepreneurs becomes then a critical condition in the middle of this scenario because the financing system for big actors of the economy has little to do with the type of needs that usually report modest and independent entrepreneurs. This results in a greater intervention of informal investors that contribute with very discrete amounts that, depending on the beneficiary's abilities and preparation and the market demand, can result in a high volatility of activities as GEM data are reporting.

The next sections provide a comprehensive analysis of the internal composition of the selected four conditions and the differences that arise when comparing their configuration under the light of the experts' perception in South Africa, Angola, Mozambique and Madagascar.

\section{Deep analysis of the financing for entrepreneurs' condition}

Like in the previous section, the results presented in this section will only cover South Africa, Angola, Mozambique and Madagascar as they represent the most recent SubSaharan participants in GEM.

Access to funding is a universal problem for most intentional entrepreneurs. However, GEM studies over the years have shown that the "lack of funding is not unique to any one country especially those in developing economies but rather that there is a universal 
problem probably caused by a rift between what the entrepreneur is able to offer and what the funders require". In both factor-driven and efficiency-driven economies, entrepreneurs are not able to present an acceptable business plan that clearly shows what distinguishes the benefits of the product or service on offer to what is already on the market (Herrington \& Kew, 2017). Market research is often inadequate and poorly conducted resulting in a failure of the business venture before it really starts. In South Africa, there is an abundance of potential funders, but for a variety of reasons the funding is not getting to the entrepreneurs who need it. However, the situation is different in Angola, Mozambique and Madagascar where there is a lack of government subsidies, business angels, venture capitalist and IPOs (see Table 3 below) although there are a number of informal investors available but not in the quantity required.

In order to better understand the state of entrepreneurial financing in these countries, a principal component analysis on the expert's data, the results which are shown in Table 4, indicate that the financing context has different internal configurations for the four countries. The first is that in South Africa and Angola, the financial context is explained by three components, whereas in Madagascar and Mozambique, by two. The weights of the eight sources of funding evaluated by each expert are different in each country suggesting that each scenario has its own peculiarities. South Africa and Angola show a more sophisticated structure than either Madagascar or Mozambique. For example, in South Africa, the three components for the financing of entrepreneurs are government subsidies (0.891), IPOs (0.795) and debt funding (0.701); on the other hand, the professional investment sources as they are venture capitalists (0.723), private lenders (0.918) and business angels (0.723) and finally, the third component represents the funding available from equity (0.765) and informal investors (0.864). The last two rows of the table show that the three dimensions have similar influence and capacity to explain the state of finance for entrepreneurs $(27.48 \%, 26.385$ and $26.33 \%$, respectively).

Table 3 Average expert rating for the availability of entrepreneurial finance in selected subSaharan Africa countries

\begin{tabular}{|c|c|c|c|c|}
\hline Scale: $1=$ completely false, $9=$ completely true & $\begin{array}{l}\text { South } \\
\text { Africa* }\end{array}$ & Angola & Mozambique & Madagascar \\
\hline $\begin{array}{l}\text { In my country, there is sufficient equity funding available for } \\
\text { new and growing businesses. }\end{array}$ & 4.62 & 4.03 & 2.06 & 2.64 \\
\hline $\begin{array}{l}\text { In my country, there is sufficient debt funding for new and } \\
\text { growing businesses. }\end{array}$ & 4.76 & 3.42 & 2.06 & 3.56 \\
\hline $\begin{array}{l}\text { In my country, there are sufficient government subsidies } \\
\text { available for new and growing businesses. }\end{array}$ & 4.64 & 3.17 & 2.26 & 1.78 \\
\hline $\begin{array}{l}\text { In my country, there is sufficient funding available from informal } \\
\text { investors who are private individuals for new and growing } \\
\text { businesses. }\end{array}$ & 4.36 & 5.31 & 3.17 & 4.61 \\
\hline $\begin{array}{l}\text { In my country, there is sufficient business angels funding } \\
\text { available for new and growing businesses. }\end{array}$ & 4.16 & 2.97 & 2.20 & 2.71 \\
\hline $\begin{array}{l}\text { In my country, there are sufficient venture capitalists available for } \\
\text { new and growing businesses. }\end{array}$ & 4.41 & 2.54 & 1.22 & 3.67 \\
\hline $\begin{array}{l}\text { In my country, there is sufficient funding available through initial } \\
\text { public offerings (IPOs) for new and growing businesses. }\end{array}$ & 3.69 & 1.88 & 1.30 & 1.55 \\
\hline $\begin{array}{l}\text { In my country, there is sufficient private lender's funding } \\
\text { available (crowding) for new and growing businesses. }\end{array}$ & 3.51 & 1.83 & 1.81 & 2.74 \\
\hline
\end{tabular}

*Averages are simple, not weighted as these are simple items. The scores for South Africa correspond to the year 2017 and the rest to 2018 
Table 4 Principal component analyses on access to financing for entrepreneurs in South Africa, Angola, Madagascar and Mozambique: correlations between the single items and the principal components and explanatory capacity

\begin{tabular}{|c|c|c|c|}
\hline South Africa & Official sources & $\begin{array}{l}\text { Private } \\
\text { professional } \\
\text { sources }\end{array}$ & $\begin{array}{l}\text { Own and } \\
\text { informal } \\
\text { sources }\end{array}$ \\
\hline $\begin{array}{l}\text { Government subsidies available for new } \\
\text { and growing firms }\end{array}$ & 0.891 & 0.075 & 0.123 \\
\hline $\begin{array}{l}\text { Initial public offerings (IPOs) for new and } \\
\text { growing firms }\end{array}$ & 0.795 & 0.394 & -0.057 \\
\hline $\begin{array}{l}\text { Debt funding available for new and } \\
\text { growing firms }\end{array}$ & 0.701 & 0.056 & 0.634 \\
\hline $\begin{array}{l}\text { Equity funding available for new and } \\
\text { growing firms }\end{array}$ & 0.371 & 0.121 & 0.765 \\
\hline $\begin{array}{l}\text { Venture capitalists for new and growing } \\
\text { firms }\end{array}$ & 0.332 & 0.723 & 0.356 \\
\hline $\begin{array}{l}\text { Private lenders' funding (crowd funding) } \\
\text { available for new and growing firms }\end{array}$ & 0.135 & 0.918 & -0.077 \\
\hline $\begin{array}{l}\text { Professional business angels for new } \\
\text { and growing firms }\end{array}$ & 0.054 & 0.732 & 0.471 \\
\hline $\begin{array}{l}\text { Informal investors (family, friends and } \\
\text { colleagues) for new and growing firms }\end{array}$ & -0.114 & 0.171 & 0.864 \\
\hline $\begin{array}{l}\% \text { of variance explained or weight of the } \\
\text { component }\end{array}$ & $27.48 \%$ & $26.38 \%$ & $26.33 \%$ \\
\hline $\begin{array}{l}\text { Total } \% \text { of variance explained by the } 3 \\
\text { components }\end{array}$ & $27.48+26.38+26.33=$ & $80.20 \%$ & \\
\hline Angola & $\begin{array}{l}\text { Government, venture } \\
\text { capital and BA }\end{array}$ & $\begin{array}{l}\text { Equity, crowd } \\
\text { funders and IPOs }\end{array}$ & $\begin{array}{l}\text { Debt, banks } \\
\text { versus informal }\end{array}$ \\
\hline $\begin{array}{l}\text { Venture capitalists for new and growing } \\
\text { firms }\end{array}$ & 0.860 & -0.028 & 0.087 \\
\hline $\begin{array}{l}\text { Professional business angels for new and } \\
\text { growing firms }\end{array}$ & 0.807 & 0.313 & -0.070 \\
\hline $\begin{array}{l}\text { Government subsidies available for new } \\
\text { and growing firms }\end{array}$ & 0.595 & 0.129 & 0.508 \\
\hline $\begin{array}{l}\text { Initial public offerings (IPOs) for new and } \\
\text { growing firms }\end{array}$ & 0.445 & 0.516 & -0.302 \\
\hline $\begin{array}{l}\text { Debt funding available for new and } \\
\text { growing firms }\end{array}$ & 0.338 & 0.103 & 0.727 \\
\hline $\begin{array}{l}\text { Private lenders' funding (crowdfunding) } \\
\text { available for new and growing firms }\end{array}$ & 0.235 & 0.908 & 0.071 \\
\hline $\begin{array}{l}\text { Informal investors (family, friends and } \\
\text { colleagues) for new and growing firms }\end{array}$ & 0.213 & 0.128 & -0.724 \\
\hline $\begin{array}{l}\text { Equity funding available for new and } \\
\text { growing firms }\end{array}$ & -0.032 & 0.836 & 0.010 \\
\hline $\begin{array}{l}\% \text { of variance explained or weight of } \\
\text { the component }\end{array}$ & $26.98 \%$ & $24.13 \%$ & $17.72 \%$ \\
\hline $\begin{array}{l}\text { Total } \% \text { of variance explained by the } 3 \\
\text { components }\end{array}$ & \multicolumn{3}{|c|}{$26.98 \%+24.13 \%+17.72 \%=68.84 \%$} \\
\hline Madagascar & \multicolumn{2}{|l|}{ Investment sources } & sources \\
\hline $\begin{array}{l}\text { Equity funding available for new and } \\
\text { growing firms }\end{array}$ & -0.094 & 0.836 & \\
\hline $\begin{array}{l}\text { Debt funding available for new and } \\
\text { growing firms }\end{array}$ & 0.241 & 0.752 & \\
\hline $\begin{array}{l}\text { Government subsidies available for new } \\
\text { and growing firms }\end{array}$ & 0.638 & 0.532 & \\
\hline Informal investors (family, friends and & -0.059 & 0.755 & \\
\hline
\end{tabular}


Table 4 Principal component analyses on access to financing for entrepreneurs in South Africa, Angola, Madagascar and Mozambique: correlations between the single items and the principal components and explanatory capacity (Continued)

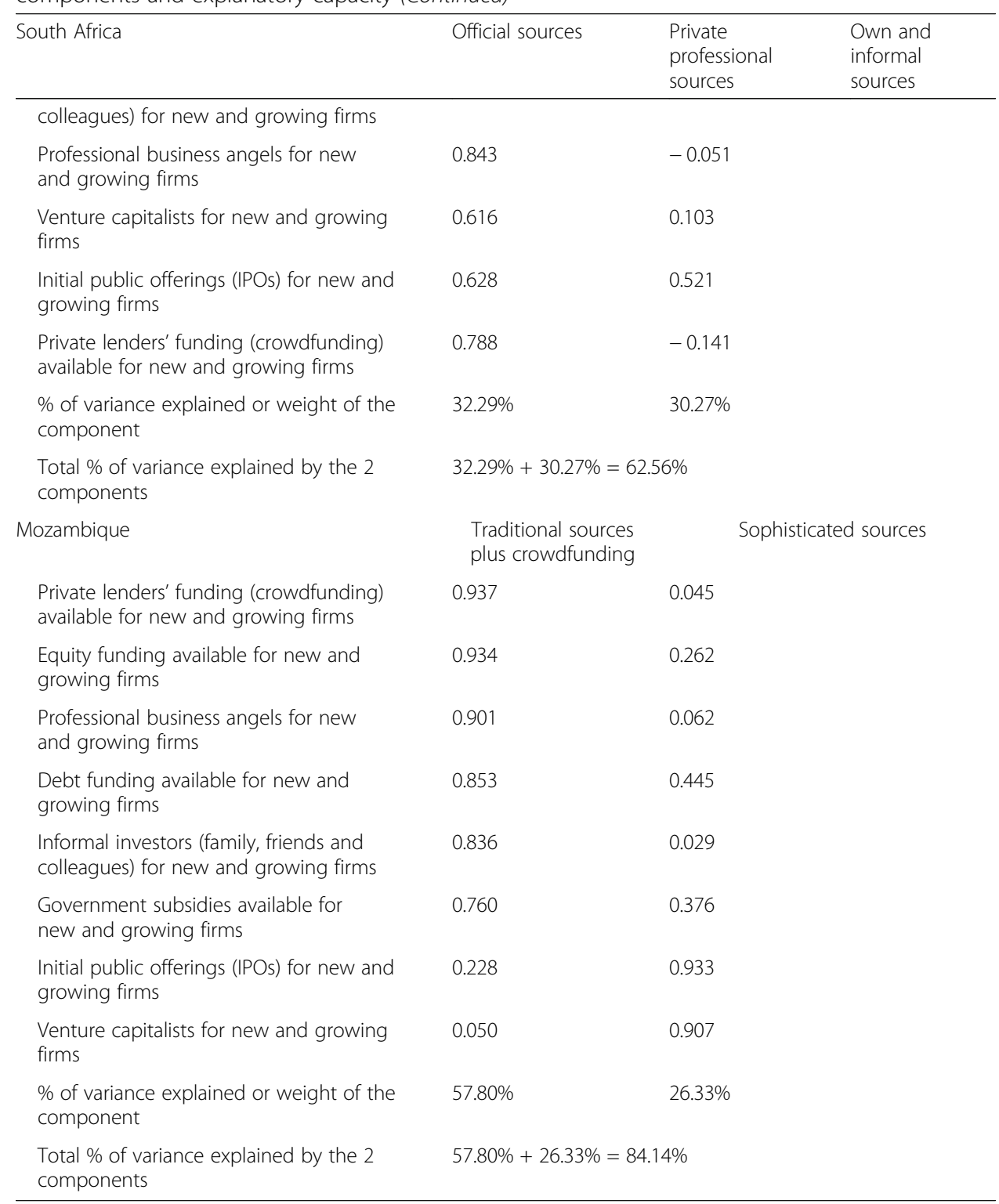

In the case of Angola, the configuration for the state of access to financing is different. The first dimension represents the state of government, venture capitalists and business angels. The second-dimension aggregates crowdfunding, equity funds and IPOs. In this case, IPOs have a lower correlation (0.516) than either private lenders (0.908) or equity funding $(0.836)$ which indicates that it has low relevance in the financing for entrepreneur's context. The third dimension represents banks (0.727) and informal investors $(-0.724)$ with opposite signs and similar weights. The negative sign for informal investment means that the state of financing for entrepreneurs gets better when the presence of banks increases while it gets worse when informal investors grow. Hence, in a developing country like Angola, informal investment is not the solution to 
improve finance to entrepreneurs but rather they require funds from more powerful sources such as venture capitalists and angel investors.

In Madagascar and Mozambique, the condition for financing is explained by two dimensions. For Madagascar the experts divided this condition into two components representing those from investment sources (venture capitalists, business angels, stockholders and crowd funders) and those from traditional sources; however, for Mozambique, the experts are divided into traditional channels and the more sophisticated sources such as venture capitalist, business angels, etc. This shows that in Mozambique the source of funding comes more from traditional sources rather than for the more sophisticated sources.

\section{Deep analysis of the government policies condition}

Government policies can play an important role in the entrepreneurial pipeline as to whether an intentional entrepreneur actually takes the step to start a business. GEM has always recognized that it is not government's responsibility to start new businesses but it is definitely their responsibility to create an economic climate that is conducive to starting a business and that as many barriers as possible are removed to make it easier for an entrepreneur to start a new venture, succeed and hopefully create new jobs. However, Table 5 shows that the expert ratings for government policies are especially low in Mozambique and Madagascar and that in all four countries, bureaucracy, regulations and licencing requirements significantly hinder businesses from starting. In these countries, much is talked about reducing the "cost of red tape" but in reality, very little is achieved due to inefficiency, lack of suitable experience and corruption.

Principal components analysis on the expert informant's data (Table 6) shows that this condition is explained by two components in three countries (South Africa, Angola and Mozambique) and by three components in Madagascar. In South Africa and Mozambique, the block on government policies is summarized by the two components

Table 5 Average expert ratings for government policies for entrepreneurship in selected subSaharan African countries

\begin{tabular}{|c|c|c|c|c|}
\hline Scale: $1=$ completely false, $9=$ completely true & South Africa & Angola & Mozambique & Madagascar \\
\hline $\begin{array}{l}\text { Government policies (e.g. public procurement) } \\
\text { consistently favour new firms }\end{array}$ & 3.42 & 3.09 & 1.75 & 2.82 \\
\hline $\begin{array}{l}\text { Support for new and growing businesses is a high } \\
\text { priority at a national government level }\end{array}$ & 4.23 & 4.29 & 1.82 & 3.51 \\
\hline $\begin{array}{l}\text { Support for new and growing businesses is a high } \\
\text { priority at a local government level }\end{array}$ & 4.00 & 3.09 & 1.79 & 3.51 \\
\hline $\begin{array}{l}\text { Most firms can get most of the required permits } \\
\text { and licences in about a week }\end{array}$ & 2.06 & 2.50 & 2.67 & 3.13 \\
\hline $\begin{array}{l}\text { The amount of taxes is not a burden to new and } \\
\text { growing businesses }\end{array}$ & 3.08 & 3.36 & 2.00 & 2.55 \\
\hline $\begin{array}{l}\text { Taxes and other government regulations and } \\
\text { applied to new and growing businesses in a } \\
\text { predictable and consistent way }\end{array}$ & 4.93 & 5.24 & 3.48 & 4.14 \\
\hline $\begin{array}{l}\text { Coping with government bureaucracy, regulations } \\
\text { and licencing requirements is not unduly difficult } \\
\text { for new and growing businesses }\end{array}$ & 2.77 & 3.14 & 2.00 & 3.26 \\
\hline
\end{tabular}

Averages are simple, not weighted as these are simple items. The scores for South Africa correspond to the year 2017 and the rest to 2018 
Table 6 Principal component analyses on government policies for entrepreneurs in South Africa, Angola, Madagascar and Mozambique: correlations between the single items and the principal components and explanatory capacity

\begin{tabular}{|c|c|c|}
\hline South Africa & $\begin{array}{l}\text { Regulations, } \\
\text { taxes, } \\
\text { bureaucracy }\end{array}$ & Government support \\
\hline $\begin{array}{l}\text { Government policies (e.g. public procurement) } \\
\text { consistently favour new firms }\end{array}$ & 0.357 & 0.645 \\
\hline $\begin{array}{l}\text { The support for new and growing firms is a high } \\
\text { priority for policy at the national government } \\
\text { level }\end{array}$ & -0.182 & 0.890 \\
\hline $\begin{array}{l}\text { The support for new and growing firms is a high } \\
\text { priority for policy at the local government level }\end{array}$ & 0.150 & 0.788 \\
\hline $\begin{array}{l}\text { New firms can get most of the required permits } \\
\text { and licences in about a week }\end{array}$ & 0.696 & 0.221 \\
\hline $\begin{array}{l}\text { The amount of taxes is not a burden for new } \\
\text { and growing firms }\end{array}$ & 0.854 & 0.173 \\
\hline $\begin{array}{l}\text { Taxes and other government regulations are } \\
\text { applied to new and growing firms in a } \\
\text { predictable and consistent way }\end{array}$ & 0.697 & 0.112 \\
\hline $\begin{array}{l}\text { Coping with government bureaucracy, } \\
\text { regulations, and licencing requirements, it is not } \\
\text { unduly difficult for new and growing firms }\end{array}$ & 0.831 & -0.217 \\
\hline $\begin{array}{l}\% \text { of variance explained or weight of the } \\
\text { component }\end{array}$ & $36.76 \%$ & $28.13 \%$ \\
\hline $\begin{array}{l}\text { Total \% of variance explained by the } 2 \\
\text { components }\end{array}$ & \multicolumn{2}{|c|}{$36.73 \%+28.13 \%=64.90 \%$} \\
\hline Angola & $\begin{array}{l}\text { Government } \\
\text { support }\end{array}$ & $\begin{array}{l}\text { Regulations, taxes, } \\
\text { bureaucracy }\end{array}$ \\
\hline $\begin{array}{l}\text { Government policies (e.g. public procurement) } \\
\text { consistently favour new firms }\end{array}$ & 0.812 & 0.330 \\
\hline $\begin{array}{l}\text { The support for new and growing firms is a high } \\
\text { priority for policy at the national government } \\
\text { level }\end{array}$ & 0.867 & -0.044 \\
\hline $\begin{array}{l}\text { The support for new and growing firms is a high } \\
\text { priority for policy at the local government level }\end{array}$ & 0.819 & -0.073 \\
\hline $\begin{array}{l}\text { New firms can get most of the required permits } \\
\text { and licences in about a week }\end{array}$ & 0.256 & 0.710 \\
\hline $\begin{array}{l}\text { The amount of taxes is not a burden for new } \\
\text { and growing firms }\end{array}$ & -0.437 & 0.558 \\
\hline $\begin{array}{l}\text { Taxes and other government regulations are } \\
\text { applied to new and growing firms in a } \\
\text { predictable and consistent way }\end{array}$ & 0.159 & 0.512 \\
\hline $\begin{array}{l}\text { Coping with government bureaucracy, } \\
\text { regulations, and licencing requirements, it is not } \\
\text { unduly difficult for new and growing firms }\end{array}$ & -0.312 & 0.693 \\
\hline $\begin{array}{l}\% \text { of variance explained or weight of the } \\
\text { component }\end{array}$ & $35.13 \%$ & $23.90 \%$ \\
\hline $\begin{array}{l}\text { Total } \% \text { of variance explained by the } 2 \\
\text { components }\end{array}$ & \multicolumn{2}{|c|}{$35.13 \%+23.90 \%=59.05 \%$} \\
\hline Mozambique & $\begin{array}{l}\text { Regulations, } \\
\text { taxes, } \\
\text { bureaucracy }\end{array}$ & Government support \\
\hline $\begin{array}{l}\text { Government policies (e.g. public procurement) } \\
\text { consistently favour new firms }\end{array}$ & 0.692 & -0.031 \\
\hline $\begin{array}{l}\text { The support for new and growing firms is a high } \\
\text { priority for policy at the national government }\end{array}$ & -0.008 & 0.980 \\
\hline
\end{tabular}
level 
Table 6 Principal component analyses on government policies for entrepreneurs in South Africa, Angola, Madagascar and Mozambique: correlations between the single items and the principal components and explanatory capacity (Continued)

\begin{tabular}{|c|c|c|c|}
\hline South Africa & $\begin{array}{l}\text { Regulations, } \\
\text { taxes, } \\
\text { bureaucracy }\end{array}$ & Government support & \\
\hline $\begin{array}{l}\text { The support for new and growing firms is a high } \\
\text { priority for policy at the local government level }\end{array}$ & -0.007 & 0.985 & \\
\hline $\begin{array}{l}\text { New firms can get most of the required permits } \\
\text { and licences in about a week }\end{array}$ & 0.941 & -0.009 & \\
\hline $\begin{array}{l}\text { The amount of taxes is not a burden for new } \\
\text { and growing firms }\end{array}$ & 0.766 & 0.095 & \\
\hline $\begin{array}{l}\text { Taxes and other government regulations are } \\
\text { applied to new and growing firms in a } \\
\text { predictable and consistent way }\end{array}$ & 0.638 & 0.563 & \\
\hline $\begin{array}{l}\text { Coping with government bureaucracy, } \\
\text { regulations, and licencing requirements, it is not } \\
\text { unduly difficult for new and growing firms }\end{array}$ & 0.852 & 0.027 & \\
\hline $\begin{array}{l}\% \text { of variance explained or weight of the } \\
\text { component }\end{array}$ & $44.05 \%$ & $32.26 \%$ & \\
\hline $\begin{array}{l}\text { Total } \% \text { of variance explained by the } 2 \\
\text { components }\end{array}$ & $44.05 \%+32.26$ & $\%=76.31 \%$ & \\
\hline Madagascar & $\begin{array}{l}\text { Government } \\
\text { support }\end{array}$ & $\begin{array}{l}\text { Regulations, taxes, } \\
\text { bureaucracy: } \\
\text { procedures }\end{array}$ & $\begin{array}{l}\text { Regulations, taxes, } \\
\text { bureaucracy: } \\
\text { formality }\end{array}$ \\
\hline $\begin{array}{l}\text { Government policies (e.g. public procurement) } \\
\text { consistently favour new firms }\end{array}$ & 0.699 & 0.335 & -0.300 \\
\hline $\begin{array}{l}\text { The support for new and growing firms is a high } \\
\text { priority for policy at the national government } \\
\text { level }\end{array}$ & 0.836 & 0.192 & 0.266 \\
\hline $\begin{array}{l}\text { The support for new and growing firms is a high } \\
\text { priority for policy at the local government level }\end{array}$ & 0.821 & 0.013 & 0.210 \\
\hline $\begin{array}{l}\text { New firms can get most of the required permits } \\
\text { and licences in about a week }\end{array}$ & 0.183 & 0.784 & -0.113 \\
\hline $\begin{array}{l}\text { The amount of taxes is not a burden for new } \\
\text { and growing firms }\end{array}$ & 0.277 & 0.805 & 0.105 \\
\hline $\begin{array}{l}\text { Taxes and other government regulations are } \\
\text { applied to new and growing firms in a } \\
\text { predictable and consistent way }\end{array}$ & 0.268 & 0.011 & 0.883 \\
\hline $\begin{array}{l}\text { Coping with government bureaucracy, } \\
\text { regulations, and licencing requirements, it is not } \\
\text { unduly difficult for new and growing firms }\end{array}$ & -0.350 & 0.617 & 0.473 \\
\hline $\begin{array}{l}\% \text { of variance explained or weight of the } \\
\text { component }\end{array}$ & $30.94 \%$ & $25.60 \%$ & $17.60 \%$ \\
\hline $\begin{array}{l}\text { Total \% of variance explained by the } 3 \\
\text { components }\end{array}$ & \multicolumn{3}{|c|}{$30.94 \%+25.60 \%+17.60 \%=74.15 \%$} \\
\hline
\end{tabular}

(regulations, taxes and bureaucracy and government support) but in South Africa the component representing the effectiveness of regulations, taxes and bureaucracy weighs more (36.76\%) than government support (28.13\%), while in Angola, the weight of government support $(35.13 \%)$ is higher than the weight for regulations $(23.9 \%)$. This means that in South Africa and in Mozambique, emphasis should be placed on improving the regulatory system in favour of government support whereas the opposite is true for Angola.

In Madagascar, the analysis of this condition results in three instead of two components with the emphasis being placed on government support (30.94\%) followed by 
regulations as associated to procedures $(25.60 \%)$ and regulations associated to formality (17.60\%).

In conclusion, the state of government support is mainly explained by two components, one representing the support from government and the other representing regulation, taxes and bureaucracy. However, the different countries show significant differences in that in Mozambique and South Africa, the regulatory part is more determinant than the government support, while in Angola and Madagascar the opposite is true.

\section{Deep analysis of the government programmes condition}

Over the years, GEM key expert informants have emphasized how difficult it is to access basic information from the government about starting a business. In all the countries, government has introduced many programmes to promote entrepreneurial development. However, studies by Herrington and Kew (2017) have shown in South Africa that awareness of these programmes within the adult population is low and their usage even lower. Again, this is more evident in Mozambique and Madagascar where a lack of experience and funding is the main restraining factor (Table 7). Even when there is adequate funding as is the case with South Africa, awareness of government programmes remains very low and amongst the lowest in most developing countries.

Individual principal component analysis on government programmes for the four countries show there is only one component in the case of Angola and two for the other three countries as shown in Table 8. The results suggest that in the case of South Africa, special attention needs to be paid to the effectiveness of the government programmes, while in Madagascar and Mozambique, there is a definite lack of offered resources.

\section{Deep analysis of the education and training condition}

GEM has consistently shown that the higher the level of education, the more likely the entrepreneur is to start a business and for the business to grow and prosper. There is a

Table 7 Average expert ratings for government programmes for entrepreneurship in selected subSaharan African countries

\begin{tabular}{lllll}
\hline Scale: 1 = completely false, $9=$ completely true & South Africa* & Angola & Mozambique & Madagascar \\
\hline $\begin{array}{l}\text { A wide range of government assistance for new } \\
\text { and growing firms can be obtained through }\end{array}$ & 2.68 & 4.06 & 3.75 & 2.27 \\
$\begin{array}{l}\text { a single agency } \\
\begin{array}{l}\text { Science parks and business incubators provide } \\
\text { effective support for new and growing businesses }\end{array}\end{array}$ & 4.56 & 2.69 & 3.17 & 3.97 \\
$\begin{array}{l}\text { There are an adequate number of government } \\
\text { programmes for new and growing businesses }\end{array}$ & 4.02 & 3.09 & 2.23 & 2.72 \\
$\begin{array}{l}\text { The people who work in government agencies } \\
\text { are competent and effective in supporting new } \\
\text { and growing businesses }\end{array}$ & 2.61 & 3.03 & 2.68 & 3.29 \\
$\begin{array}{l}\text { Almost anyone who needs help from a government } \\
\text { programme for new and growing businesses can } \\
\text { find what they want }\end{array}$ & 2.48 & 2.56 & 2.03 & 3.03 \\
$\begin{array}{l}\text { Government programmes aimed at supporting } \\
\text { new and growing businesses are effective }\end{array}$ & 3.35 & 2.85 & 2.71 & 2.89 \\
\hline
\end{tabular}

*Averages are simple, not weighted as these are simple items. The scores for South Africa correspond to the year 2017 and the rest to 2018 
Table 8 Principal component analyses on government programmes for entrepreneurs in South Africa, Angola, Madagascar and Mozambique: correlations between the single items and the principal components and explanatory capacity

\begin{tabular}{|c|c|c|}
\hline South Africa & Offer & Effectiveness \\
\hline $\begin{array}{l}\text { A wide range of government assistance for new and growing } \\
\text { firms can be obtained through contact with a single agency }\end{array}$ & 0.392 & 0.440 \\
\hline $\begin{array}{l}\text { Science parks and business incubators provide effective support } \\
\text { for new and growing firms }\end{array}$ & -0.037 & 0.915 \\
\hline $\begin{array}{l}\text { There are an adequate number of government programmes } \\
\text { for new and growing businesses }\end{array}$ & 0.738 & 0.155 \\
\hline $\begin{array}{l}\text { The people working for government agencies are competent } \\
\text { and effective in supporting new and growing firms }\end{array}$ & 0.862 & 0.118 \\
\hline $\begin{array}{l}\text { Almost anyone who needs help from a government programme } \\
\text { for a new or growing business can find what they need }\end{array}$ & 0.732 & 0.163 \\
\hline $\begin{array}{l}\text { Government programmes aimed at supporting new and growing } \\
\text { firms are effective }\end{array}$ & 0.499 & 0.728 \\
\hline$\%$ of variance explained or weight of the component & $37.13 \%$ & $27.10 \%$ \\
\hline Total $\%$ of variance explained by the 2 components & $37.13 \%+27.10 \%=64.23 \%$ & \\
\hline Angola & Government programmes & \\
\hline $\begin{array}{l}\text { A wide range of government assistance for new and growing } \\
\text { firms can be obtained through contact with a single agency }\end{array}$ & 0.598 & \\
\hline $\begin{array}{l}\text { Science parks and business incubators provide effective support } \\
\text { for new and growing firms }\end{array}$ & 0.642 & \\
\hline $\begin{array}{l}\text { There are an adequate number of government programmes for } \\
\text { new and growing businesses }\end{array}$ & 0.812 & \\
\hline $\begin{array}{l}\text { The people working for government agencies are competent } \\
\text { and effective in supporting new and growing firms }\end{array}$ & 0.856 & \\
\hline $\begin{array}{l}\text { Almost anyone who needs help from a government programme } \\
\text { for a new or growing business can find what they need }\end{array}$ & 0.870 & \\
\hline $\begin{array}{l}\text { Government programmes aimed at supporting new and growing } \\
\text { firms are effective }\end{array}$ & 0.880 & \\
\hline$\%$ of variance explained or weight of the component & $61.52 \%$ & \\
\hline Madagascar & Effectiveness & Offer \\
\hline $\begin{array}{l}\text { A wide range of government assistance for new and growing } \\
\text { firms can be obtained through contact with a single agency }\end{array}$ & 0.041 & 0.841 \\
\hline $\begin{array}{l}\text { Science parks and business incubators provide effective } \\
\text { support for new and growing firms }\end{array}$ & 0.239 & 0.771 \\
\hline $\begin{array}{l}\text { There are an adequate number of government programmes } \\
\text { for new and growing businesses }\end{array}$ & 0.406 & 0.744 \\
\hline $\begin{array}{l}\text { The people working for government agencies are competent } \\
\text { and effective in supporting new and growing firms }\end{array}$ & 0.823 & 0.332 \\
\hline $\begin{array}{l}\text { Almost anyone who needs help from a government programme } \\
\text { for a new or growing business can find what they need }\end{array}$ & 0.775 & 0.346 \\
\hline $\begin{array}{l}\text { Government programmes aimed at supporting new and } \\
\text { growing firms are effective }\end{array}$ & 0.816 & 0.014 \\
\hline$\%$ of variance explained or weight of the component & $36.11 \%$ & $34.74 \%$ \\
\hline Total $\%$ of variance explained by the 2 components & $36.11 \%+34.74 \%=70.85 \%$ & \\
\hline Mozambique & Effectiveness & Offer \\
\hline $\begin{array}{l}\text { A wide range of government assistance for new and growing } \\
\text { firms can be obtained through contact with a single agency }\end{array}$ & 0.452 & -0.716 \\
\hline $\begin{array}{l}\text { Science parks and business incubators provide effective } \\
\text { support for new and growing firms }\end{array}$ & 0.087 & 0.521 \\
\hline $\begin{array}{l}\text { There are an adequate number of government programmes } \\
\text { for new and growing businesses }\end{array}$ & 0.373 & 0.659 \\
\hline
\end{tabular}

for new and growing businesses 
Table 8 Principal component analyses on government programmes for entrepreneurs in South Africa, Angola, Madagascar and Mozambique: correlations between the single items and the principal components and explanatory capacity (Continued)

\begin{tabular}{lll}
\hline South Africa & Offer & Effectiveness \\
\hline $\begin{array}{l}\text { The people working for government agencies are competent } \\
\text { and effective in supporting new and growing firms }\end{array}$ & 0.592 & 0.443 \\
$\begin{array}{l}\text { Almost anyone who needs help from a government programme } \\
\text { for a new or growing business can find what they need }\end{array}$ & 0.914 & 0.246 \\
$\begin{array}{l}\text { Government programmes aimed at supporting new and } \\
\text { growing firms are effective }\end{array}$ & 0.863 & -0.138 \\
$\begin{array}{l}\text { \% of variance explained or weight of the component } \\
\text { Total \% of variance explained by the 2 components }\end{array}$ & $38.03 \%$ & $24.89 \%$ \\
\hline
\end{tabular}

direct correlation between the levels of perceived capabilities and the level of early-stage entrepreneurial activity in the countries. The items that describe this condition and their average scores are shown in Table 9. The evaluations suggest a weak state for this condition except in the case of certain aspects with respect to Madagascar. Thus, experts' opinions clearly show that in all countries, the quality of primary and secondary education in entrepreneurship is clearly lacking especially in Mozambique and Madagascar and that the education system does not provide adequate instruction in market economic principles or in preparing young people to become independent of the formal job market and to start their own businesses. However, there is an improvement in the level of business and vocational training but not enough to satisfy the market needs.

The principal component analysis for the state of entrepreneurship education and training gives just one component for South Africa and Angola as shown in Table 10 but two for Madagascar and Mozambique. This clearly shows that the national experts in Madagascar show that there are two components to be considered where the educational standards at school level are worse than at the post-school stage, whereas in Mozambique, entrepreneurial education at a school and college level needs serious

Table 9 Average expert ratings for entrepreneurial education and training in selected sub-Saharan African countries

\begin{tabular}{llllc}
\hline Scale: 1 = completely false, $9=$ completely true & $\begin{array}{l}\text { South } \\
\text { Africa* }\end{array}$ & Angola & Mozambique & Madagascar \\
\hline $\begin{array}{l}\text { Teaching in primary and secondary education encourages } \\
\text { creativity, self-sufficiency and personal initiative }\end{array}$ & 3.00 & 3.19 & 2.18 & 2.64 \\
$\begin{array}{l}\text { Teaching in primary and secondary education provides } \\
\text { adequate instruction in market economic principles }\end{array}$ & 2.98 & 2.57 & 1.86 & 2.23 \\
$\begin{array}{l}\text { Teaching in primary and secondary education provides } \\
\text { adequate attention to entrepreneurship and new firm creation }\end{array}$ & 2.49 & 3.48 & 1.28 & 2.13 \\
$\begin{array}{l}\text { Colleges and universities provide good and adequate } \\
\text { preparation for starting up and growing new firms }\end{array}$ & 3.88 & 3.29 & 2.00 & 4.46 \\
$\begin{array}{l}\text { The level of business and management education provides } \\
\text { good and adequate preparation for starting up and growing } \\
\text { new firms }\end{array}$ & 4.46 & 4.11 & 3.04 & 6.13 \\
$\begin{array}{l}\text { The vocational, professional and continuing education systems } \\
\text { provide good and adequate preparation for starting and } \\
\text { growing new firms }\end{array}$ & 4.22 & 4.06 & 3.09 & 5.95
\end{tabular}

*Averages are simple, not weighted as these are simple items. The scores for South Africa correspond to the year 2017 and the rest to 2018 
Table 10 Principal component analyses on entrepreneurial education and training in South Africa, Angola, Madagascar and Mozambique: correlations between the single items and the principal components and explanatory capacity

\begin{tabular}{|c|c|c|}
\hline South Africa & $\begin{array}{l}\text { Entrepreneurial } \\
\text { education and training }\end{array}$ & \\
\hline $\begin{array}{l}\text { In my country, teaching in primary and } \\
\text { secondary education encourages creativity, } \\
\text { self-sufficiency and personal initiative }\end{array}$ & 0.862 & \\
\hline $\begin{array}{l}\text { In my country, teaching in primary and } \\
\text { secondary education provides adequate } \\
\text { instruction in market economic principles }\end{array}$ & 0.864 & \\
\hline $\begin{array}{l}\text { In my country, teaching in primary and } \\
\text { secondary education provides adequate } \\
\text { attention to entrepreneurship and new } \\
\text { firm creation }\end{array}$ & 0.888 & \\
\hline $\begin{array}{l}\text { In my country, colleges and universities } \\
\text { provide good and adequate preparation } \\
\text { for starting up and growing new firms }\end{array}$ & 0.762 & \\
\hline $\begin{array}{l}\text { In my country, the level of business and } \\
\text { management education provides good } \\
\text { and adequate preparation for starting up } \\
\text { and growing new firms }\end{array}$ & 0.711 & \\
\hline $\begin{array}{l}\text { In my country, the vocational, professional } \\
\text { and continuing education systems provide } \\
\text { good and adequate preparation for starting } \\
\text { up and growing new firms }\end{array}$ & 0.768 & \\
\hline $\begin{array}{l}\% \text { of variance explained or weight of the } \\
\text { component }\end{array}$ & $65.90 \%$ & \\
\hline Angola & $\begin{array}{l}\text { Entrepreneurial } \\
\text { education and training }\end{array}$ & \\
\hline $\begin{array}{l}\text { In my country, teaching in primary and } \\
\text { secondary education encourages creativity, } \\
\text { self-sufficiency and personal initiative }\end{array}$ & 0.598 & \\
\hline $\begin{array}{l}\text { In my country, teaching in primary and } \\
\text { secondary education provides adequate } \\
\text { instruction in market economic principles }\end{array}$ & 0.642 & \\
\hline $\begin{array}{l}\text { In my country, teaching in primary and } \\
\text { secondary education provides adequate } \\
\text { attention to entrepreneurship and new } \\
\text { firm creation }\end{array}$ & 0.812 & \\
\hline $\begin{array}{l}\text { In my country, colleges and universities } \\
\text { provide good and adequate preparation } \\
\text { for starting up and growing new firms }\end{array}$ & 0.856 & \\
\hline $\begin{array}{l}\text { In my country, the level of business and } \\
\text { management education provides good } \\
\text { and adequate preparation for starting up } \\
\text { and growing new firms }\end{array}$ & 0.870 & \\
\hline $\begin{array}{l}\text { In my country, the vocational, professional } \\
\text { and continuing education systems provide } \\
\text { good and adequate preparation for starting } \\
\text { up and growing new firms }\end{array}$ & 0.880 & \\
\hline $\begin{array}{l}\% \text { of variance explained or weight of the } \\
\text { component }\end{array}$ & $76.27 \%$ & \\
\hline Madagascar & $\begin{array}{c}\text { Entrepreneurial } \\
\text { education at school } \\
\text { stages }\end{array}$ & $\begin{array}{l}\text { Entrepreneurial } \\
\text { education at post- } \\
\text { school stages }\end{array}$ \\
\hline $\begin{array}{l}\text { In my country, teaching in primary and } \\
\text { secondary education encourages creativity, } \\
\text { self-sufficiency and personal initiative }\end{array}$ & 0.852 & 0.119 \\
\hline In my country, teaching in primary and & 0.847 & 0.170 \\
\hline
\end{tabular}


Table 10 Principal component analyses on entrepreneurial education and training in South Africa, Angola, Madagascar and Mozambique: correlations between the single items and the principal components and explanatory capacity (Continued)

\begin{tabular}{|c|c|c|}
\hline South Africa & \multicolumn{2}{|l|}{$\begin{array}{l}\text { Entrepreneurial } \\
\text { education and training }\end{array}$} \\
\hline \multicolumn{3}{|l|}{$\begin{array}{l}\text { secondary education provides adequate } \\
\text { instruction in market economic principles }\end{array}$} \\
\hline $\begin{array}{l}\text { In my country, teaching in primary and } \\
\text { secondary education provides adequate } \\
\text { attention to entrepreneurship and new } \\
\text { firm creation }\end{array}$ & 0.936 & 0.042 \\
\hline $\begin{array}{l}\text { In my country, colleges and universities } \\
\text { provide good and adequate preparation for } \\
\text { starting up and growing new firms }\end{array}$ & 0.167 & 0.734 \\
\hline $\begin{array}{l}\text { In my country, the level of business and } \\
\text { management education provides good and } \\
\text { adequate preparation for starting up and } \\
\text { growing new firms }\end{array}$ & -0.010 & 0.931 \\
\hline $\begin{array}{l}\text { In my country, the vocational, professional and } \\
\text { continuing education systems provide good and } \\
\text { adequate preparation for starting up and growing } \\
\text { new firms }\end{array}$ & 0.162 & 0.892 \\
\hline$\%$ of variance explained or weight of the component & $39.54 \%$ & $37.44 \%$ \\
\hline Total $\%$ of variance explained by the 2 components & \multicolumn{2}{|c|}{$39.54 \%+37.44 \%=76.98 \%$} \\
\hline Mozambique & $\begin{array}{l}\text { Entrepreneurial } \\
\text { education at school } \\
\text { and college }\end{array}$ & $\begin{array}{l}\text { Specific education to } \\
\text { start up businesses }\end{array}$ \\
\hline $\begin{array}{l}\text { In my country, teaching in primary and secondary } \\
\text { education encourages creativity, self-sufficiency } \\
\text { and personal initiative }\end{array}$ & 0.934 & 0.196 \\
\hline $\begin{array}{l}\text { In my country, teaching in primary and secondary } \\
\text { education provides adequate instruction in market } \\
\text { economic principles }\end{array}$ & 0.915 & 0.072 \\
\hline $\begin{array}{l}\text { In my country, teaching in primary and secondary } \\
\text { education provides adequate attention to entrepreneurship } \\
\text { and new firm creation }\end{array}$ & -0.008 & 0.855 \\
\hline $\begin{array}{l}\text { In my country, colleges and universities provide good } \\
\text { and adequate preparation for starting up and growing } \\
\text { new firms }\end{array}$ & 0.855 & 0.302 \\
\hline $\begin{array}{l}\text { In my country, the level of business and management } \\
\text { education provides good and adequate preparation for } \\
\text { starting up and growing new firms }\end{array}$ & 0.453 & 0.702 \\
\hline $\begin{array}{l}\text { In my country, the vocational, professional and continuing } \\
\text { education systems provide good and adequate preparation } \\
\text { for starting up and growing new firms }\end{array}$ & 0.651 & 0.656 \\
\hline$\%$ of variance explained or weight of the component & $51.18 \%$ & $29.81 \%$ \\
\hline Total $\%$ of variance explained by the 2 components & \multicolumn{2}{|c|}{$51.18 \%+29.81 \%=80.99 \%$} \\
\hline
\end{tabular}

attention more than specific education to start up businesses. In South Africa and Angola, there is an overall problem with the education system which is not adequate.

\section{Recommendations for policy and practice}

An important focus of the GEM National Expert Survey is not only to identify key weaknesses in the entrepreneurial environment, but also to obtain recommendations that can be used to inform policy decisions and stimulate entrepreneurial activity. The GEM theoretical framework generally assumes that the better the state of the 
conditions, the greater the likelihood that entrepreneurs will be able to develop initiatives that are successful and that contribute positively to economic development. Annual correlation analyses performed by GEM between the average state of EFCs and the GEM countries' GPD per capita give empirical support to this assumption. For example, for the year 2018, over a sample of 49 economies, the four conditions analysed in this paper, show positive and significant correlations with the countries' GDP per capita. In the case of financing for entrepreneurs, the coefficient was 0.360 ( $p$ value $=0.011$ ); in the case of government concrete policies, priority and support, it was 0.443 ( $p$ value $=0.001$ ); in the case of taxes and bureaucracy, it was 0.518 ( $p$ value $=0.000)$; in the case of government programmes, it was 0.586 ( $p$ value $=0.000)$; in the case of entrepreneurship education at school stage, it was 0.506 ( $p$ value $=0.000)$; and finally, in the case of entrepreneurship education at post-school stage, it was $0.330(p$ value $=0.021)$. The results strongly suggest that improving these EFCs can have a positive impact in the economic growth of GEM countries.

However, the four countries in this study are markedly different from an economic and development point of view from other economies of the world and, due to the persistence of income inequality and lack of inclusive growth problems, it is difficult to expect a fast and efficient change of the entrepreneurship context. Additionally, Madagascar, Mozambique and Angola are factor-driven, low-income countries whereas South Africa is an efficiency-driven, middle-income country, which can allow that society to perform this transformation process more quickly. In conclusion, only general recommendations can be made as each country is different and has a different political history with respect to colonialization.

\section{Conclusions}

The main factors inhibiting entrepreneurial development will be discussed.

1. Access to finance

(a) Help prepare small businesses so that they are financially ready to start a business by providing adequate practical training

(b) Government subsidies and guarantees should be available to all viable small businesses as was originally done in South Africa via the Khula Finance Guarantee Scheme (Herrington, Kew, \& Kew, 2009).

(c) Allow angel investors and venture capitalists to write off their investment in the first year and not to have to amortize it over many years which increases their risk. This is being done in Israel with much success. (Herrington, 2017).

2. Government policies and practices

(a) Reduce the number of regulatory requirements on small businesses. Remove unnecessary bureaucratic burdens and onerous labour laws

(b) Make it easier for businesses to register, open a bank account and comply with tax regulations thereby allowing businesses to run their businesses and not be bogged down by pointless and unproductive administration

(c) Corruption needs to be addressed as soon as possible. There should be serious implications for corruption and harsh sentences handed down.

(d) High levels of crime in all countries needs to be addressed 


\section{Education and training}

(a) The focus on primary and secondary education must be on improving the quality of education especially with respect to both literacy and numeracy skills.

(b) At every level of education, the system should be geared to teaching competences that skill students to think freely and not to rely on large organizations to provide employment but rather to teach the young population to create their own opportunities.

(c) It is important to improve the skills gap by introducing interventions such as apprenticeships and technical and vocational training.

(d) Post-school education should consider the introduction of new subjects in the use of digital platforms to start businesses, to capitalize on the use of big data, to identify market niches, new ways of approaching customers, market analysis and many more. The rapidly changing environment requires radical thinking in the new ways of working and the use of new tools.

\section{Abbreviations}

APS: Adult Population Survey; EFCs: Entrepreneurship framework conditions; GDP: Gross national product; GEM: Global Entrepreneurship Monitor; MENA: Middle East and North Africa; NES: National Expert Survey; OECD: Organisation of Economic Community Development; SSA: Sub-Saharan Africa; WEF: World Economic Forum

\section{Acknowledgements}

The authors wish to acknowledge the contribution of Francis Carmona.

\section{Authors' contributions}

$\mathrm{MH}$ wrote the introduction, literature review, and some of the results. AC wrote the statistical analysis section of the paper. All authors read and approved the final manuscript.

\section{Funding}

The funding for this project was provided by the International Development Research Centre of Canada and the Small Enterprise Development Agency if the Department of Trade and Industry in South Africa.

\section{Competing interests}

The authors declare that they have no competing interests.

Received: 30 May 2019 Accepted: 28 August 2019

Published online: 30 October 2019

\section{References}

Acs, Z. J., Autio, E., \& Szerb, L. (2014). National systems of entrepreneurship measurement issue and policy recommendations. Research Policy, 43, 476-494.

African Economic Outlook. (2017). Entrepreneurship and industrialisation. Paris: OECD Publishing. https://doi.org/10.1787/aeo-2017-en. Aghion, P. (2017). Entrepreneurship and growth: Lessons from an intellectual journey. Small Business Economics., 48(1), 9-24. Anyanwu, J. C. (2013). Determining the correlates of poverty for inclusive growth in Africa. Tunis, Tunisia: Working Paper Series $N^{\circ} 181$ African Development Bank.

Atiase, V. Y., Mahmood, S., Wang, Y., \& Botchie, D. (2018). Developing entrepreneurship in Africa: Investigating critical resource challenges. Journal of Small Business and Enterprise Development, 25(4), 644-666.

Beugre, C. D. (2016). Building entrepreneurial ecosystems in sub-Saharan Africa: A quintuple helix model. Palgrave Studies of Entrepreneurship in Africa. New York: Springer Nature. https://doi.org/10.1057/978-1-137-56894-6. ISBN 978-1-137-56893-9

Bosma, N., \& Kelley, D. (2019). Global Entrepreneurship Monitor 2018/2019 Global Report. Babson College.

Bruton, G., Khavul, S., Siegel, D., \& Wright, M. (2015). New financial alternatives in seeding entrepreneurs: Microfinance, crowdfunding and peer-to-peer innovations. Entrepreneurship Theory and Practice., 39, 9-26.

Chigunta, F. (2017). Enterprise as a possible solution to youth unemployment. Labour and Learning, 433-451.

Dvoulety, O., \& Orel, M. (2019). Entrepreneurial activity and its determinants: Findings from African developing countries. In Sustainable Entrepreneurship: The role of collaboration in the global economy. Springer.

GEM Global Report, 2017/18. London business School.

George, G., Kotha, R., Parikh, P., Alnuaimi, T., \& Bahaj, A. S. (2016). Social structure, reasonable gain and entrepreneurship in Africa. Strategic Management Journal, 37(6), 1118-1131.

Gomes, E., Vendrell - Herrero, F., Mellahi, K., Angwin, D., \& Sousa, C. M. P. (2018). Testing self-selection theory in high corruption environments; evidence from African SMEs. International Marketing Review. https://doi.org/10.1108/IMR-03-2017-0054.

Herrington, M. (2017) Policy briefs, Global Entrepreneurship Research Association, London Business School.

Herrington, M., Kew, J. and Kew, P. (2009). Tracking entrepreneurship in South Africa: A GEM perspective, University of Cape Town. Herrington, M. and Kew, P. (2015). Global Entrepreneurship Monitor South Africa Report 2015, University of Cape Town. Herrington, M. and Kew, P. (2017). Global Entrepreneurship Monitor South African Report 2017/18, University of Cape Town. Herrington, M. Kew, P., Mwanga, A. (2016). Global Entrepreneurship Monitor South African Report 2016/17., University of Cape Town. 
International Labour Organization: World employment social outlook, 2018

Kuada, J. (2015). Entrepreneurship in Africa - a classificatory framework and research agenda. African Journal of Economic and Management Studies, 6(2), 148-163.

Lafuente, E., Szerb, L., \& Acs, Z. J. (2016). Country level efficiency and natural systems of entrepreneurship: A data development analysis approach. Journal of Technology Transfer., 42(6), 1260-1283.

Lafuente, F., Vaillant, Y., \& Leiva, J. C. (2018). Sustainable and traditional product innovation with scale and experience, but only for KIBS. Sustainability, 10(4), 1169.

McKinsey Global Institute (2017). A future that works: Automation, employment and productivity.

Munemo, J. (2012). Entrepreneurship in developing countries: Is Africa different? Journal of Development Entrepreneurship, $17(01), 1250004$

Ndulu, R., Chakraborti, L., Lijane, L., Ramachadram, V., \& Wolgin, J. (2007). The challenges of African growth - opportunities, constraints and strategic directions. Washington DC: The International Bank for Reconstruction and Development, World Bank.

OECD. (2012). Policy brief on youth entrepreneurship. Published de L'OECD.

Ratten, V., \& Jones, P. (2018). Bringing Africa into entrepreneurship research. In African Entrepreneurship (pp. 9-27). Cham: Palgrave Macmillan.

Reynolds, P. D., Hay, M., \& Camp, M. S. (1999). Global Entrepreneurship Monitor 1999 executive report. London Business School. Sheriff, M., Muffatto, M. and Cooper, S. (2016). Measuring entrepreneurship environments in Africa: challenges in using international reports. International Journal of Entrepreneurship and Innovation Management, Vol. 20, No. 1/2, pp. $20-44$.

Sub-Saharan Africa. (2018). Sub-Saharan Africa restarting the growth engine. In Regional Economic Outlook $2017 / 18$ (p. 122). Washington DC: International Monetary Fund.

Sutton, C., Bruton, G. D., \& Chen, J. (2019). Entrepreneurship as a solution to extreme poverty: A review and future research directions. Journal of Business Venturing, 34, 197-214

Szerb, L., Lafuente, E., Horvath, K., \& Pager, B. (2018). The relevance of quantity and quality entrepreneurship for regional performance: The moderating role of the entrepreneurial ecosystem. Regional Studies. https://doi.org/10.1080/00343404.2018.1510481.

Welt De (2019) https://www.welt.de/English-news/article 4021638, 29 June 2009.

Williams, C. C., Martinez-Perez, A., \& Kedir, A. M. (2017). Informal entrepreneurship in developing economies: The impact of starting up unregistered on firm performance. Entrepreneurship Theory and Practice., 41(5), 773-799.

World Economic Forum, 2016. Outlook on the global agenda, 2015 pdf. http://www.WEFum.org

\section{Publisher's Note}

Springer Nature remains neutral with regard to jurisdictional claims in published maps and institutional affiliations.

\section{Submit your manuscript to a SpringerOpen ${ }^{\circ}$ journal and benefit from:}

- Convenient online submission

- Rigorous peer review

- Open access: articles freely available online

- High visibility within the field

- Retaining the copyright to your article

Submit your next manuscript at $\boldsymbol{\nabla}$ springeropen.com 